\title{
The Role of Workload and Work Discipline in Improving Job Satisfaction and Performance of Outsourcing Employees
}

\author{
Sudarsih $^{1}$, Supriyadi ${ }^{2}$ \\ ${ }^{1}$ Faculty of Economics and Business, Universitas Jember \\ Kalimantan Road No. 37, Jember 68132, Indonesia \\ ${ }^{2}$ Agribussiness Management, State Polytechnic of Jember \\ Mastrip Road, Jember 68101, Indonesia
}

\begin{abstract}
:
Outsourcing employees are contract employees supplied from an outsourcing service provider company. This study examines how to improve outsourcing employees' performance through workload and work discipline using job satisfaction as intervening variable. As many as 43 outsourcing workers at PT Bank Rakyat Indonesia Jember are involved as samples. The sampling techniques used is census because it uses entire population as samples. This study used quantitative data through the distribution of questionnaires. Path analysis is performed for the purpose of this study. The results exhibit significant direct negative impact of workload on employee's job satisfaction and performance, significant direct positive impact of work discipline on employee's job satisfaction and performance, and significant direct positive and significant effect of job satisfaction on employees' performance. The results also found significant indirect effects of workload and discipline on employee performance with job satisfaction as intervening variable but the magnitude is weaker than its direct effect.
\end{abstract}

Keywords: Employee Performance, Job Satisfaction, Workload, Work Discipline

\section{Introduction}

Employee performance is one of strategic aspects for the company to reach its goal. Performance is generally interpreted as a individual's success in perform their job. The performance of employee is the outcome of work attained by someone in carrying out the duties assigned to him to achieve the work target. Employees will be able to perform well if they have high performance so they can execute excellent job. Employee performance is one of the determinants of the company's success in achieving its objectives. Thus, performance of the employees should be leader's concern, because the decline in employee performance can affect the overall achievement of the company. The level of success of a company can be seen from the performance of the company in managing the resources it has. Companies with good performance, have effectiveness in handling production, handle their human resources, and determine targets that must be achieved both individually and organizationally (Armstrong, 2004: 29). One factor needed to be considered by the company so that the performance of its human resources is workload.

Workload is the amount of assignment that should be carried by an organizational unit and is the yield times between the number of jobs and time. An effort must be made to harmonize work capacity, workload and work environment so that optimal work productivity can be obtained and every worker can work healthily without harm himself and the surrounding community (Health Act No. 36 of 2009). The workload of employees is in the form of work targets and working hours charged. The workload charged to employees must be in accordance with the capabilities and regulations applied. In determining the workload for employee, it is necessary to perform workload analysis.

According to Komaruddin (1996: 235), workload analysis is a mechanism to specify the hours number a person works or is required to complete a job in a certain time. Workload analysis purposes to 
determine how many personnel and proper responsibilities or work is delegated to an employee. According to Simamora (2006), workload analysis is identifying both the number of officers and their qualifications needed to achieve goals of organization. But excessive and unsuitable workload can cause fatigue and work stress on employees resulting in low employee job satisfaction and employee performance.

The next factor related to employee performance is discipline. Discipline is an individual's willingness and awareness to fullfil all applicable company regulations and social norms (Hasibuan, 2009: 193). Thus, work discipline can be interpreted as awareness and loyalty of employees to carry out and to complete their task by always obeying company regulations. The attitude of employee discipline can be shown by coming and going home on time, doing all the work well, obeying company's regulations and also the prevailing social norms. Employee discipline is a form of effort that seeks to improve and to shape the knowledge, attitudes, and also behavior of employees which later they can perform the work cooperatively with their counterparts and improve work performance (Siagian, 2001: 305). As employees obey the rules set by the company and having high discipline, it will create a more conducive corporate atmosphere then it will have a positive result on the company's activities. Therefore, every company has the hope that company employees can comply with the regulations that have been set so that employees can work optimally.

Workload and work discipline are factors that can influence employee job satisfaction in the company. Job satisfaction refers to an emotional situation of pleasant and it represents an individual's feeling for their job (Handoko, 1987: 193). Robbins (2010: 78) defines job satisfaction as an attitude about individual's work showing the disparity between what the employees received and what they believe they should receive. The higher the level of employees' job satisfaction in the company, the higher the sense of comfort in working in the company and the ability to improve work performance.

PT Bank Rakyat Indonesia (BRI) Jember Branch is a branch company of PT Bank Rakyat Indonesia (BRI) engaged in the banking sector. This company is located at Jl. A. Yani No. 1 Jember, Indonesia. In this study, the empirical studies done on outsourcing workers of PT Bank Rakyat Indonesia (BRI) Jember
Branch. According to Maurice Greaver, outsourcing is the act of diverting some of the company's activities and the right of decision making to other parties (outside providers), where this action is bound in a cooperation contract. In Law Number 13 of 2003 concerning Employment, outsourcing is regulated in articles 64 to 66 . The law does not explicitly explain the definition of outsourcing, but what is referred to as outsourcing, we can see the meaning in article 64 of the Act - Law Number 13 of 2003 concerning Manpower, which states that a company can surrender a portion of its work to another company through an agreement to contract work or Provision of services for workers or laborers made in writing. Outsourced employees cannot be equated with permanent employees, because outsourcing employees carry out company activities delegated to them that are bound by a cooperation contract. Based on some sources, working in a banking company has a lot of time spent at work so there is little time to take care of family, house, and other leisure time. This study purposes to examine the effect of workload and work discipline on employee performance using job satisfaction as mediating variable.

\section{Literature Review}

\subsection{The Effect of Workload on Job Satisfaction}

Some studies showed the relationship between workload and employee's job satisfaction variable. Ali and Farooqi (2014) evidenced that work stress appears because some factor such as overload work that can affect job satisfaction. The workload given to employees must be adjusted to the ability and type of work itself through considerations by looking at various related aspects. Excessive workload can have an effect on fatigue and health problems of employees, which in turn can lead to job dissatisfaction. Parimita, et al. (2017) also found the negative and significant influence of workload on job satisfaction of PT. Askrindo's employees in Jakarta.

$\mathrm{H}_{1}$ : Workload has a significant negative effect on job satisfaction.

\subsection{The Effect of Work Discipline on Job Satisfaction}

Work discipline is defined as an behavior, attitude, and actions that are in accordance with the rules of organization, whether it is written or not. Basically, every employee is required to have a high level of discipline, such as being present on time in the office, 
leaving the work desk after the office hours, and working on the assignments to achieve the intended target. From high employee discipline there will be a level of employee satisfaction at work. Employees and superiors will feel satisfied if the employee does the task according to the specified target. Sari et al (2017) found that work discipline affect job satisfaction of teacher in Medan, Indonesia positively and significantly. Cedaryana et al (2018) also found that work discipline has a significant positive impact on job satisfaction among employee of Ministry Research, Technology and Higher Education in Jakarta.

$\mathrm{H}_{2}$ : Work discipline has a significant positive effect on job satisfaction.

\subsection{The Effect of Workload on Employee}

Performance

Workload is an individual extrinsic factor that becomes one source of the emergence of performance problems, because the workload faced is too much. This condition requires employees to provide greater energy than usual in completing their work, not all employees have a level of resistance to pressure from the same workload, but all of this depends on each individual, meaning the tasks will be completed properly depending on how someone lives the workload he feels. Artadi (2015) revealed that workload has a positive influence on employee performance where workload pressure can be positive, and this leads to improved performance. Shah, et al. (2011) stated that workload has a positive effect on performance where high workloads make performance assessments performed by supervisors very important, because they are related to performance and the amount of bonuses that employees will receive. If the workload continues to increase without the division of the appropriate workload, the employee's performance will decrease. Excessive workload occurs when officers are commanded to complete more work tasks than the available time. Shabbir and Raza (2017) and Harini et al (2018) also found that excessive workload has a significant influence on the performance of human resource in a company.

$\mathrm{H}_{3}$ : Workload has a significant negative effect on employee performance.

2.4 The Effect of Work Discipline on Employee

\section{Performance}

Hasibuan (2017: 193) stated that discipline is someone's willingness and awareness to applicate all company's rule, whether it is written or not, and its social norms. Work discipline becomes a priority thing in a company, because with the discipline of the company, life becomes safe, orderly, smooth and the company's goals are achieved. The more employees are disciplined at work, the more advanced their performance. Conversely, if employees are less disciplined at work, it will lead to the worsen performance. A research by Cedaryana et al (2018) evidenced that work discipline has a positive influence on employee performance. Mangkunegara and Waris (2015) also stated that good discipline will improve employee performance and will help the company to reach its goal.

$\mathrm{H}_{4}$ : Work dicipline has a significant positive effect on employee performance.

\subsection{The Effect of Job Satisfaction on Employee}

\section{Performance}

Job satisfaction has an important and prominent role for each company, because job satisfaction contributes to improve employee performance. Employee's job satisfaction must be considered, because an employee who feels satisfied will show a positive attitude towards his work. This positive attitude is shown by enthusiasm and discipline in work, so that they stand on improving their performance. When employees are satisfied with what they have done in work, their performance will be advanced. Inuwa (2016) found out that job satisfaction has a significant positive reaction on nonacademic staff's performance in Nigeria. Fadlallh (2015) also discovered that good work conditions, good pay and promotion, and good work relationship can induce higher job satisfaction which then affect employee performance in Saudi Arabia.

$\mathrm{H}_{5}$ : Job satisfaction has a significant positive effect on employee performance.

\section{Methodology}

The research design in this article is explanatory research which aims to explain the relationship among variables through the process of hypothesis testing. The type of data used in the form of quantitative data. Data sources used in this study include primary data obtained directly from original 
sources. Data obtained from respondents in the form of questionnaire answers, data from the company in the form of the number of employees and organizational structure. This study used quantitative data through the distribution of questionnaires. This study uses a census technique that is the entire population used as a sample with 43 outsourcing workers at PT Bank Rakyat Indonesia Jember as a sample. If the number of subjects in the population only covers between 100 and in the data collection the researcher uses questionnaires or questionnaires, the subject of the number should be taken entirely (Arikunto: 2006). To examine the influence of workload and work discipline on employee performance through job satisfaction, this study used path analysis tool. Below is the path model in this study:

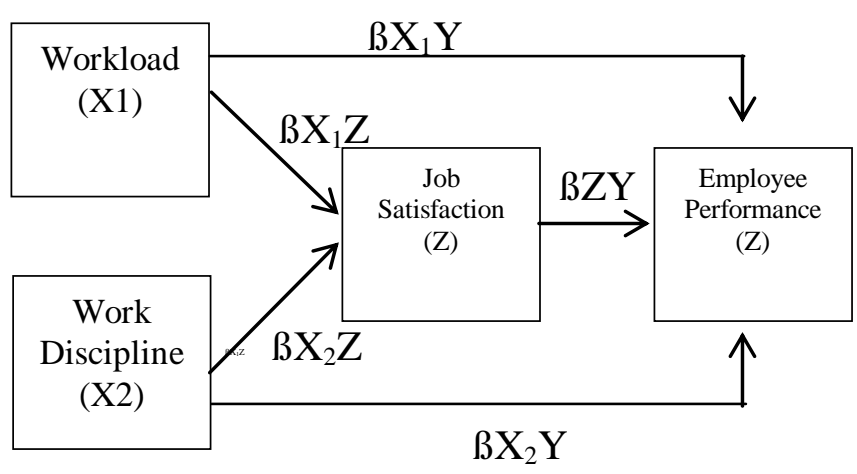

Figure 1 : Conceptual Framework

The path analysis models used in structural equations are as follows:

$\mathrm{Y} 1=\beta \mathrm{X} 1 \mathrm{Z}+\beta \mathrm{X} 2 \mathrm{Z}+\varepsilon \mathrm{i}$ equation 1

$\mathrm{Y} 2=\beta \mathrm{X} 1 \mathrm{Y}+\beta \mathrm{X} 2 \mathrm{Y}+\beta \mathrm{ZZ}+\varepsilon 2$. equation 2

Where:

$\beta=$ Coefficient of independent variables

$\mathrm{X} 1=$ Workload

$\mathrm{X} 2$ = Work discipline

$\mathrm{Z}=$ Job Satisfaction

$\mathrm{Y}=$ Employee Performance

$\varepsilon 1,2=$ residual variable / error term

\section{Result and Discussion}

4.1 Results

\section{Characteristics of Respondents}

Based on the results of the questionnaires distribution conducted on 43 respondents, the general descriptions of respondents' age and gender are shown below.
Table 1.

\begin{tabular}{|c|c|c|}
\hline \multicolumn{3}{|c|}{ Based on Age } \\
\hline Age & $\mathbf{N}$ & $\mathbf{( \% )}$ \\
\hline $20-25$ & 6 & 13,9 \\
$26-30$ & 17 & 39,5 \\
$31-35$ & 15 & 34,8 \\
$36-40$ & 5 & 11,6 \\
\hline \multicolumn{3}{|c|}{ Based on Gender } \\
\hline Gender & $\mathbf{N}$ & $\mathbf{( \% )}$ \\
\hline Male & 12 & 27,9 \\
\hline Female & 31 & 72,1 \\
\hline
\end{tabular}

Source: Processed data, 2019

Table 2. Descriptive Statistic for Respondents Answers

\begin{tabular}{|c|c|c|c|c|c|c|}
\hline \multirow{2}{*}{$\begin{array}{c}\text { Variabl } \\
\text { e }\end{array}$} & \multicolumn{5}{|c|}{ Average Answers \% } & \multirow{2}{*}{$\begin{array}{c}\text { Total } \\
\%\end{array}$} \\
\hline & $\begin{array}{c}\text { Strongl } \\
\text { y } \\
\text { Agree }\end{array}$ & $\begin{array}{c}\text { Agre } \\
\text { e }\end{array}$ & $\begin{array}{l}\text { Neutr } \\
\text { al }\end{array}$ & $\begin{array}{c}\text { Disagr } \\
\text { ee }\end{array}$ & $\begin{array}{c}\text { Strongl } \\
y \\
\text { Disagre } \\
\text { e }\end{array}$ & \\
\hline $\mathrm{X} 1$ & 26,3 & 49,5 & 30,2 & 1,5 & 0 & 100 \\
\hline $\mathrm{X} 2$ & 8,8 & 60 & 19,2 & 7 & 0 & 100 \\
\hline $\mathrm{Z}$ & 30,6 & 48,8 & 5,18 & 0 & 0 & 100 \\
\hline $\mathrm{Y}$ & 25,2 & 58,6 & 27,9 & 0,4 & 0 & 100 \\
\hline
\end{tabular}

Source : Processed data, 2019

As shown on Table 1, the outsourcing employees of PT BRI Jember are dominated with employees with age range of 25-30 years old. Based on gender, the majority of employees are females. According to Table 2, out of 43 respondents, majority of them are agree and strongly and show positive opinion about the indicators of workload, work discipline, job satisfaction, and employee performance variable.

\section{Normality Test of Data}

The normality test was carried out using the Kolmogorov Smirnov. The data are normally distributed if the significance value is larger than $\alpha=5 \%$. After performing the Kolmogorov Smirnov test, the result shows that each variable has a normal data distribution, this is seen from Sig. value which is greater than $\alpha=5 \%$, thus the data in the study are worth using.

\section{Path Analysis}

This section describes each path in the model using path analysis. Each tested pathway shows the direct and indirect effects of workload, work discipline, job satisfaction, and employee performance variable. By knowing the significance of each pathways, we will answer whether the proposed hypothesis is accepted or rejected. Each path tested represents the hypothesis that exists in this study. 
The value of path coefficient can be seen in the following table.

Table 3. The Recapitulation of Path Analysis

\begin{tabular}{|c|c|c|c|c|c|}
\hline $\begin{array}{c}\text { Depende } \\
\text { nt } \\
\text { variable }\end{array}$ & $\begin{array}{c}\text { Independent } \\
\text { variable }\end{array}$ & B & $\begin{array}{c}\mathrm{t}- \\
\text { value }\end{array}$ & Sig. & $\begin{array}{c}\text { Conclusio } \\
\mathrm{n}\end{array}$ \\
\hline \multirow{2}{*}{$\begin{array}{c}\text { Job } \\
\text { Satisfacti } \\
\text { on }\end{array}$} & Workload & $\begin{array}{c}- \\
0,307 \\
\end{array}$ & $\begin{array}{c}- \\
2,188 \\
\end{array}$ & $\begin{array}{c}0,03 \\
5 \\
\end{array}$ & $\begin{array}{c}\text { Significan } \\
\mathrm{t}\end{array}$ \\
\hline & $\begin{array}{c}\text { Work } \\
\text { Discipline }\end{array}$ & 0,337 & 2,402 & $\begin{array}{c}0,02 \\
1\end{array}$ & $\begin{array}{c}\text { Significan } \\
\mathrm{t}\end{array}$ \\
\hline \multirow{3}{*}{$\begin{array}{c}\text { Employe } \\
\text { e } \\
\text { Performa } \\
\text { nce }\end{array}$} & Workload & $\begin{array}{c}- \\
0,341\end{array}$ & $\begin{array}{c}- \\
2,735\end{array}$ & $\begin{array}{c}0,00 \\
9\end{array}$ & $\begin{array}{c}\text { Significan } \\
\mathrm{t}\end{array}$ \\
\hline & $\begin{array}{c}\text { Work } \\
\text { Discipline }\end{array}$ & 0,318 & 2,523 & $\begin{array}{c}0,01 \\
6\end{array}$ & $\begin{array}{c}\text { Significan } \\
\mathrm{t}\end{array}$ \\
\hline & $\begin{array}{c}\text { Job } \\
\text { Satisfaction }\end{array}$ & 0,319 & 2,403 & $\begin{array}{c}0,02 \\
2\end{array}$ & $\begin{array}{c}\text { Significan } \\
\mathrm{t}\end{array}$ \\
\hline
\end{tabular}

Source:SPSS Output, 2019

From the result above, the structural path equations generated are shown below:

$\mathrm{Z}=-0,307 \mathrm{X}_{1} \mathrm{Z}+0,337 \mathrm{X}_{2} \mathrm{Z}+\varepsilon 1$ equation 1

$Y=-0,341 X_{2} Z+0,318 X_{2} Z+0,319 Z Y+\varepsilon 2 \ldots$ equation 2

\section{Classical Assumption Tests}

The results of structural equation of path coefficient of the impact of workload and work discipline on employee performance through job satisfaction cannot be interpreted before the classical assumption test is carried out first, so the path equations can fulfill Best Linear Unbiased Estimator (BLUE) criteria. The first test is the multicollinearity test which aims to determine whether there is a relationship or correlation between independent variables in the study and it is shown from VIF value magnitude. The results exhibit that the VIF values generated by all independent variables are smaller than 10. This shows that multicollinearity does not exist on all independent variables in both models. The second is heteroscedasticity test which is carried out using the Glejser test. The results show that all the significance values of Glejser test are greater than $\alpha=5 \%$. This shows that there are no heteroscedasticity in all variables. The third test is normality test of model to find out whether the residual value of the regression has a normal distribution in both models. This test is carried out using P-Plot Curve. P-Plot normal curve results show that the points coincide and follow the diagonal line so that it can be concluded that the two regression models are normally distributed.

\section{Hypotheses Testing}

In this test, the distribution table is sought at $\alpha=$ $5 \%$, with degrees of freedom (df) nk-1 or 43-2-1 = 40. The results of path analysis are to find out the effect of workload and work discipline through job satisfaction on employee performance. The association between variables is tested partially and the results are as follows:

a. The Effect of Workload on Job Satisfaction

As seen on the influence of Workload (X1) on Job Satisfaction $(\mathrm{Z})$, the $\mathrm{t}$-value is greater than t-table $(2,188>2,020)$ with significance value of 0,035 which is less than $\alpha=0,05$. This indicates that $\mathrm{H} 01$ is rejected and $\mathrm{Ha} 1$ is accepted, which means workload has an impact on job satisfaction. The coefficient direction is negative, this indicates that if there is an addition in the workload, the job satisfaction will decrease.

\section{b. The Effect of Work Discipline on Job Satisfaction}

As seen on the influence of Work Discipline (X2) on Job Satisfaction $(\mathrm{Z})$, the $\mathrm{t}$-value is greater than $\mathrm{t}$ table $(2,402>2,020)$ with significance value of 0,021 which is less than $\alpha=0,05$. This indicates that $\mathrm{H} 02$ is rejected and $\mathrm{Ha} 2$ is accepted, which indicates that work discipline affects job satisfaction. The coefficient direction is positive, this indicates that if there is an increase in the work discipline variable, the job satisfaction will increase.

\section{c. The Effect of Workload on Employee Performance}

As seen on the influence of Workload (X1) on Employee Performance (Y), the t-value is greater than t-table $(2,735>2,020)$ with significance value of 0,009 which is less than $\alpha=0,05$. This indicates that $\mathrm{H} 03$ is rejected and Ha3 is accepted, which point out that there is an effect of workload on employee performance. The coefficient direction is negative, this indicates that if there is an increase in the workload variable, the employee performance will decrease.

d. The Effect of Work Discipline on Employee Performance

As seen on the influence of Work Discipline (X2) on Employee Performance (Y), the t-value is greater than $\mathrm{t}$-table $(2,523>2,020)$ with significance value of 0,016 which is less than $\alpha=0,05$. This indicates that $\mathrm{H} 04$ is rejected and Ha4 is accepted, which indicates that there is an effect of work discipline on employee performance. The coefficient direction is positive, 
this indicates that if there is an increase in the work discipline variable, the employee performance will advanced.

e. The Effect of Job Satisfaction on Employee Performance

As seen on the impact of Job Satisfaction (Z) on Employee Performance (Y), the t-value is greater than t-table $(2,403>2,020)$ with significance value of 0,022 which is less than $\alpha=0,05$. This indicates that $\mathrm{H} 05$ is rejected and Ha5 is accepted, it implies that there is an effect of job satisfaction on the performance of employees. The coefficient direction is positive, this indicates that if employee's job satisfaction increases, it will lead to the advancement of their performance.

f. The Magnitude of $\varepsilon 1$ (The Effect of Other Variables Beside $\mathrm{X} 1$ and $\mathrm{X} 2$ on Z)

$$
\begin{aligned}
\varepsilon 1 \quad & =\sqrt{ } 1-\mathrm{R} \\
= & \sqrt{ } 1-0,211 \\
= & \sqrt{ } 0,789 \\
= & 0,888 \text { or } 88,8 \%
\end{aligned}
$$

g. The Magnitude of $\varepsilon 2$ (The Effect of Other Variables Beside $\mathrm{X} 1, \mathrm{X} 2$, and $\mathrm{Z}$ on $\mathrm{Y}$ )

$$
\begin{aligned}
\varepsilon 2 & =\sqrt{ } 1-\mathrm{R} \\
= & \sqrt{ } 1-0,459 \\
= & \sqrt{ } 0,541 \\
= & 0,735 \text { or } 73,5 \%
\end{aligned}
$$

After hypothesis testing, the next step is to calculate the path coefficient. Following are the results of coefficient path calculation:

a) Direct Effect

1) The magnitude of direct effect of workload (X1) on job satisfaction (Z) is $30,7 \%$.

2) The magnitude of direct effect of work discipline (X2) on job satisfaction (Z) is $33,7 \%$.

3) The magnitude of direct effect of workload (X1) on employee performance $(\mathrm{Y})$ is $-34,1 \%$.

4) The magnitude of direct effect of work discipline (X2) on employee performance $(\mathrm{Y})$ is $31,8 \%$.

5) The magnitude of direct effect of job satisfaction (Z) on employee performance $(\mathrm{Y})$ is $31,9 \%$.
1) The magnitude of indirect effect of workload (X1) on employee performance (Y) through job satisfaction $(\mathrm{Z})$ : $(-0,307) \times(0,319)=-0,097$ or $-9,7 \%$

2) The magnitude of indirect effect of work discipline (X2) on employee performance (Y) through job satisfaction $(\mathrm{Z})$ : $(0,337) \times(0,319)=0,107$ or $10,7 \%$

c) Total Effect

1) Total Effect $: \mathrm{Y} \leftarrow \mathrm{X} 1 \rightarrow \mathrm{Z} \rightarrow \mathrm{Y},(-0,341)$ $+(-0,097)=-0,438$ or $-43,8 \%$

2) Total Effect $: \mathrm{Y} \leftarrow \mathrm{X} 2 \rightarrow \mathrm{Z} \rightarrow \mathrm{Y},(0,318)+$ $(0,107)=0,425$ or $42,5 \%$

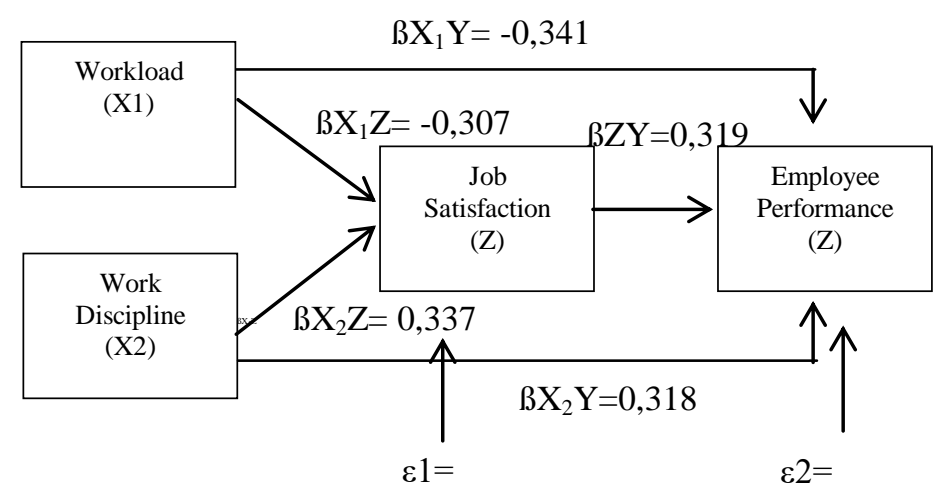

Figure 2. Coefficients of Path Analysis

\subsection{Discussion}

\section{The Effect of Workload on The Job Satisfaction of PT BRI's Employee}

The statistical result showed that there is negative and significant effect of workload on job satisfaction of PT BRI's outsourcing employee. It indicates that the increase in workload will lead to the decrease of their satisfaction. Job satisfaction is the opinion of employees who are pleasant or not about their work, such feeling can be seen from employee's good behavior towards work and all things experienced in the work environment. But often the excessive workload makes employees have to spend more energy and mind than they should. This will make a decrease in enthusiasm, work motivation, increased work stress and lead to the job dissatisfaction. Sometimes when an employee is absent, the workload will be given to other employees so that it will add to the workload of other employees without getting an additional salary. The heaviest burden is felt at the end of the month there are employees who ask for permission, this will

b) Indirect Effect 
make employees feel the workload is too heavy plus the deadline to deposit monthly reports to superiors.

This result is in accordance with a research by Ali and Farooqi (2014) who found that work stress occurred due to some factor such as work overload that can affect job satisfaction. Parimita et al (2017) also found the negative and significant effect of workload and job satisfaction on PT Askrindo's employee in Jakarta. Job satisfaction is influenced by daily workloads, that is when employees are more satisfied when they are given a lower workload.

\section{The Effect of Work Discipline on The Job Satisfaction of PT BRI's Employee}

The hypothesis test proved that there is significant unidirectional influence of work discipline on the job satisfaction of PT BRI's outsourcing employees in Jember. It indicates that the increase of work discipline will also increase their satisfaction. Companies play a strategic role in managing employees to embrace all regulations and norms that have been designed by the company so that officers can work discipline and effectively. Discipline is the compliance with regulations (law) or subject to supervision, and control. Various rules/ norms set by a company have a strategic role in establishing the discipline, so the employees can fullfil and implement these regulations. Regulation and norms are usually accompanied by sanctions if violations occur. Those sanctions could be in the form of verbal or written reprimand, position reduction, even until job dismissal. It depends on the amount of violation committed by the employee. It was intended so that the employees worked discipline and were responsible for their work. If employees have excellent work discipline, it is fathomed that they can accomplish the job description quickly and precisely then it can make them satisfied. This result is in accordance with a research by Sari, et al. (2017) who found that work discipline has positive and significant impact on job satisfaction of teacher in Medan, Indonesia. Cedaryana, et al (2018) also found that work discipline has a unidirectional and significant influence on job satisfaction among employees of Ministry Research, Technology and Higher Education in Jakarta.

\section{The Effect of Workload on The Performance of PT BRI's Employee}

The statistical result showed significant opposite effect of workload on the performance of PT BRI's outsourcing employees. It indicates that the addition of workload will lead to the decrease of their performance. Based on observation in PT BRI Jember Branch, it is still seen the poor use of working time, because there are still employees who work beyond the specified working hours to complete their work. This will certainly affect their performance, because with them working beyond the specified working hours every day, there are always work that has not been completed on time, then it will delay the completion of other work that they should finish. Thus, it is necessary for the bank to pay attention to the working hours of employees to use the best work time, because if working time is used correctly, employees can complete the tasks and obligations in a timely manner and there will no longer be delays in the implementation and collection of tasks at work. The use of work time is a very important thing and very influential to improve employee performance, because when using work time properly their work will have good results because it is fulfill predetermined standard. The magnitude of direct influence of workload on employee performance $(34,1 \%)$ is larger than the magnitude of indirect effect of workload on employee performance through job satisfaction as intervening variable $(9,7 \%)$. This result supports the results from Shabbier and Raza (2017) and Harini, et al. (2018) who also evidenced that excessive workload has a significant negative impact on the performance of human resource in a company.

\section{The Effect of Work Discipline on The Performance of PT BRI's Employee}

The hypothesis test proved that there is significant positive impact of work discipline on the performance of PT BRI's outsourcing employees in Jember. It indicates that the increase of work discipline will increase their performance. Discipline is a matter that becomes a benchmark for outsourcing employees of PT BRI Jember to find out whether the overall role of employees can be implemented properly or not. Discipline is also a trait or ability possessed by someone to obey and be able to control themselves, in order to keep abiding by the rules that have been made or agreed upon. Disciplinary action requires the punishment of employees who are unsuccessful to meet specified requirements or standards. Therefore, disciplinary effort is not applied carelessly, but requires a wise consideration. Accordingly, at PT. BRI Jember, work discipline is one of the most important operative functions and cannot be ignored because as part of the maintenance function of employees, and if the better the work discipline of employees, the higher the work performance that can be achieved. 
Undisciplined behavior that arises is a reflection of employees' negative perceptions of control carried out by leadership behavior. Conversely, an employee's disciplinary behavior that arises is a reflection of positive perceptions of the control of the boss or leader. The magnitude of direct influence of work discipline on employee performance $(31,8 \%)$ is larger than the magnitude of indirect effect of work discipline on employee performance using job satisfaction as intervening variable $(10,7 \%)$. This result supports a research by Cedaryana, et al. (2018) who discovered that work discipline has a unidirectioanl effect on employee performance. Mangkunegara and Waris (2015) also stated that good discipline will improve employee performance and ultimately achieve the company's goal.

\section{The Effect of Job Satisfaction on The Performance of PT BRI's Employee}

The statistical result showed significant positive effect of job satisfaction on the performance of PT BRI's outsourcing employee. It indicates that the enhancement of job satisfaction will lead to the increase of their performance. This relationship means that the more satisfied the employee is to the company, the better the work performance and the work results shown will be and vice versa. If someone feels satisfied in their work, their morale will increase. This encouragement can make it easier to reach the vision set by the organization. Job satisfaction affects the performance generated because job satisfaction is also correlated with a lack of sabotage of theft, doing bad work for a purpose, and spreading rumors or gossip to cause problems. This result is in accordance with a research by Khan et al (2016) who found that job satisfaction has a significant positive effect on non-academic staff's performance in Nigeria. Fadlallh (2015) also discovered that good work environments, satisfying salary, good promotion, and good work condition can raise higher job satisfaction which then affect employee performance in Saudi Arabia

\section{Conclusion}

As analyzed in the result and discussion part, this study highlights some result: (1) workload has a significant opposite impact on job satisfaction, (2) work discipline has a significant unidirectional effect on job satisfaction, (3) workload has a significant opposite effect on employee performance both directly and indirectly, (4) work discipline has a significant unidirectional influence on employee performance both directly and indirectly, (5) job satisfaction has a significant unidirectional effect on employee performance. This study can be considered as an enrichment to the study in human resource area about how to increase job satisfaction and employees' performance within an organization. For managerial implication, company needs to adjust the workload both in the capabilities and responsibilities of employees so that employees are able to provide optimal performance and achieve satisfaction for employees and companies. PT Bank Rakyat Indonesia Branch Jember must continue to improve job satisfaction for employees by creating good work discipline and through several aspects such as providing rewards for achievements achieved by employees, building good organizational communication, and improving working conditions. With the achievement of job satisfaction, employees will provide good loyalty and performance to the company so that the company's goals can be attained optimally.

\section{References}

[1] Amstrong, Michael. 2004. Performance Management. Yogyakarta: Tugu Publisher

[2] Ali,Sobla and Farooqi,A. 2014. Effect of Work Overload on Job Satisfaction, Effect of Job Satisfaction on Employee Performance and Employee Engagement (A Case of Public Sector University of Gujranwala Division). International Journal Of Multidisciplinary Sciences And Engineering, Vol. 5, No. 8, August 2014.

[3] Artadi, Febri. 2015. Pengaruh Kepuasan Kerja Dan Beban Kerja Terhadap Kinerja Karyawan pada PT. Merapi Agung Lestari. Jurnal Economica, 6(1):37.

[4] Cedaryana, Luddin,M.R., Supriyati,Y. 2018. Influence of Work Discipline, Career Development and Job Satisfaction on Employee Performance Directorate General Research and Development of Ministry Research, Technology and Higher Education. International Journal of Scientific Research and Management (IJSRM) Vol 6 Issue 2.

[5] Darmawan, Didit. 2013. Prinsip-prinsip Perilaku Organisasi. Surabaya: JP. Books.

[6] Fadlallh, A.W.A.2015. Impact of Job Satisfaction on Employees Performance an Application on Faculty of Science and Humanity Studies University of Salman Bin Abdul-Aziz-Al Aflaj. International Journal of Innovation and Research in Educational Sciences Volume 2, Issue 1, pp 26-32.

[7] Handoko, T.Hani. 1987. Manajemen personalia dan sumber daya manusia edisi 2. Yogyakarta : BPFE-Yogyakarta.

[8] Harini, S., Sudarijati, Kartiwi, N. 2018. Workload, Work Environment and Employee Performance of Housekeeping. International Journal of Latest Engineering and Management Research (IJLEMR) Vol 3 
Issue 1- pp 15-22.

[9] Hasibuan, Melayu S.P 2017. Manajemen sumber daya manusia, Cet. Delapan Belas. Remaja Rosdakarya

[10] Inuwa, M. 2016. Job Satisfaction and Employee Performance: An Empirical Approach. The Millennium University Journal; Vol. 1, No. 1; 2016

[11] Komarudin, Ahmad. 1996. Dasar-dasar Manajemen Investasi. Jakarta: Renika Cipta.

[12] Mangkunegara. 2006. Sumber Daya Manusia perusahaan. Bandung : Remaja Rosdakarya. Hal. 67

[13] Parimita,W., Pambudi,W.S., Aminah,H. 2017. The Impact Of Career Development And Workload Toward Employee Job Satisfaction At Pt Askrindo Jakarta. Jurnal Riset Manajemen Sains Indonesia (JRMSI) Vol 8, No. 1, 2017

[14] Robbins, Stephen dan Mary Coulter. 2010. Manajemen Edisi Kesepuluh jilid 2. Jakarta : Erlangga.

[15] Sari,R.F., Siburian, T.A., Wau, Y. 2017. The Effect Of Work Discipline, Job Satisfaction And Work Motivation Towards Teacher Organizational Commitment In Smp Negeri Of Medan Kota District. IOSR Journal of Research \& Method in Education (IOSR-JRME) Volume 7, Issue 5 Ver. I (Sep. - Oct. 2017), PP 45-54

[16] Shabbir,B and Raza Naqvi. 2017. Impact of Workload and Job Complexity on Employee Job Performance with the Moderating Role of Social Support and Mediating Role of Job Stress: A Study of Travel agencies in Rawalpindi, Islamabad and AJK. Journal of Accounting \& Marketing Vol 6 Issue 12017.

[17] Shah, S. S. H. et al. 2011. Workload and Performance of Employees. Interdisciplinary Journal of Contemporary Research in Business. Vol 3, No. 5.

[18] Siagian, Sondang. 2001. Manajemen Sumber daya manusia. Jakarta: Bumi aksara.

[19] Simamora, Henry. 2006. Manajemen Sumber Daya Manusia Edisi Kedua. Yogyakarta: Bagian Penerbitan Sekolah Tinggi Ilmu Ekonomi YKPN.Sugiyono. 2007. Metodologi Penelitian Bisnis. Bandung : Alfabeta. 